\title{
Effect of Panchagavya on Growth and Yield of Abelmoschus esculentus cv. Arka Anamika
}

\author{
Suchitra Rakesh", S. Poonguzhali, B. Saranya, S. Suguna and K. Jothibasu \\ Thanthai Roever Institute of Agriculture and Rural Development, \\ Perambalur - 621 115, Tamil Nadu, India \\ *Corresponding author
}

A B S T R A C T

\section{Keywords \\ Growth, Yield, \\ Panchagavya, \\ Biochemical, \\ Abelmoschus \\ esculentus. \\ Article Info \\ Accepted: \\ 28 August 2017 \\ Available Online: \\ 10 September 2017}

A field experiment was conducted in Thanthai Roever Institute of Agriculture and Rural Development (TRIARD), Perambalur field to find the variation in biochemical, growth, and yield parameters of Abelmoschus esculentus under different concentrations (Control, 1\%, 3\%, 5\% and 7\%) of panchagavya, and physic-chemical and biochemical properties were increased in 3\% concentration. Since there was increase in growth and yield parameters at low concentration of panchagavya, it is recommended that the panchagavya can be used for spray after diluted properly to $3 \%$.

\section{Introduction}

Heavy use of chemicals in agriculture has weakened the ecological base in addition to degradation of soil, water resources and quality of the food. At this juncture, a keen awareness has sprung on the adoption of "organic farming" as a remedy to cure the ills of modern chemical agriculture (Kannaiyan, 2000). With increased awareness on organic farming among the farming community, they are using many organic formulations in crop production for increasing the yield. The indiscriminate use of chemical pesticides in modern agriculture resulted in the development of several problems such as pesticide resistant insects, resurgences of target and non-target pests, destruction of beneficial organism like honey bee, pollinators, parasitors, and predators and pesticide residues in food and fodder. The awareness about the health and environmental problems due to the continuous use of pesticides resulted in the development of integrated pest management (IPM) and organic farming (Thomas and Prabhu, 2001; Prabhu, 2004).

Traditional organic formulation may contain numerous plant growth-promoting bacteria (PGPR), which may enhance plant growth by nitrogen fixation, growth hormone production and control phytopathogens (Amalraj et al., 2013; Naik and Sreenivasa, 2009). In many 
Asian countries, farmers formulate their own organic formulations by fermentation or composting. For example, in India, Panchagavya (PG) is one of the widely used traditional organic formulations, which is mostly prepared by farmers themselves.

Panchagavya is a term used in Ayurveda fermented product made from five ingredients obtained from cow, such as milk, urine, dung, curd and clarified butter (Amalraj et al., 2013). Role of foliar applied panchagavya in production of many plantation crops has been well documented in India (Selvaraj, 2003). Panchagavya is a popular foliar nutrition prepared by organic growers of Tamil Nadu as an indigenous material and used widely for agricultural and horticultural crops (Swaminathan et al., 2007). The present investigation was hypothesized to examine the effect of foliar application of panchagavya on different physiological parameters, yield and yield attributes of Abelmoschus esculentus.

\section{Materials and Methods}

The seeds of Abelmoschus esculentus (Hybrid - Arka anamika) were collected from the ROEVER KVK, Perambalur, Tamil Nadu. Panchagavya was prepared using the ingredients as mentioned in table 1. All these substrates were added to a wide mouthed mud pot and kept open under shade. The contents were stirred twice a day for about 20 minutes both in the morning and evening to facilitate aerobic microbial activity. After fifteen days of incubation, the fermented product "Panchagavya" was used for further studies. Care should be taken not to mix any buffalo product. The products of local breeds of cow have more potency than exotic breeds. It should be kept in the shade and covered with a wired mesh or plastic mosquito net to prevent houseflies from laying eggs and the formation of maggots in the solution. Panchagavya can be stored for 60 days.

\section{Design of the experiment}

Experiment Period: Jan 2017 to March 2017

Experimental Design: Randomised Block Design

Crop studied: Abelmoschus esculentus

\section{Treatments}

T1 - control

$\mathrm{T} 2-1 \%$ panchagavya spray

$\mathrm{T} 3-3 \%$ panchagavya spray

T4 $-5 \%$ panchagavya spray

$\mathrm{T} 5-7 \%$ panchagavya spray

Field experiment was carried out to assess panchagavya foliar spray and seed treatment and also to arrive at the suitable dilution factor to change the growth and yield of Abelmoschus esculentus. The field experiment was conducted during January2017 to March2017 at TRIARD field, Perambalur, Tamil Nadu.

\section{Physico-chemical and biological properties}

Samples were drawn on weekly basis up to 6 weeks after preparation for the nutrients and microbial estimations. The $\mathrm{pH}$ of the sample was measured using a $\mathrm{pH}$ meter (Systronics: Model 335). Electrical conductivity (EC) was determined with the help of an EC meter (Elico: Model CM 180). The major nutrients such as nitrogen, phosphorus and potassium present in panchagavya were estimated by following microkjeldhal method (Jackson. 1973), Vanadomolybdate phosphoric yellow colour method (Jackson, 1967) and Flame photometry (Jackson, 1973) respectively. The micronutrients present in organic liquid manures were estimated using Atomic Absorption Spectrophotometer (AAS).

The serial dilution and standard plate count method was used for isolation of total 
bacteria, fungi, actinomycetes and other biochemical groups viz., bacteria, fungi and actinomycetes using nutrient agar, Martin's rose Bengal agar and Kenknights' agar respectively. The plates were incubated at $28 \pm 2{ }^{\circ} \mathrm{C}$ for one week and the colony counts were recorded.

\section{Foliar spray}

For spray treatment, respective percentage of panchagavya solution was made. After dilution, the panchagavya solution has to be filtered before using it to spraying.

Panchagavya solution was sprayed at weekly interval up to $45^{\text {th }}$ Day After Sowing.

\section{Morphological studies}

Morphological studies were observed in Abelmoschus esculentus and plant height (centimeter scale), number of leaves; fresh weight and dry weight (electrical single pan balance) were measured in various concentrations with various intervals (vegetative, flowering and maturity stage).

\section{Estimation of Chlorophyll and carotenoid content by UV-VIS Spectrophotometer}

Chlorphyll a, b and total chlorophyll content in the fresh leaves was determined for each treatment at various stages (seedling, flowering and yielding) of Abelmoschus esculentus using the method advocated by Arnon (1949). The amount of carotenoid present in the extract was calculated by using the formula (Kirk and Allen, 1965).

\section{Yield parameters}

The yield parameters studies observed in Abelmoschus esculentus on number of fruits and fruit weight (electrical single pan balance) were measured in various concentrations in maturity stage.

\section{Results and Discussion}

\section{Physico-chemical and biological properties}

Change in nutrient status and microbial load present in panchagavya are given in table 2 . The indicated the presence of both major and micro nutrients in panchagavya in addition to different microflora especially bacteria. Presence of naturally occurring beneficial microorganisms predominantly bacteria, yeast, actinomycetes, photosynthetic bacteria and certain fungi were detected in organic liquid manures (Swaminanthan, 2005). Papen et al., (2002) reported that panchagavya contains Azotobacter, Azospirillum and phosphobacteria. Panchagavya contains microorganisms in addition to nutrients that help in improving plant growth, metabolic activities and resistance to pest and diseases. In the present study, Microbial load i.e., bacteria, fungi and actinomycetes was increased up to 21 th day $110 \times 10^{6}, 25 \times 10^{4}$ and $21 \times 10^{3}$ respectively. Effective Micro Organisms (EMO) in panchagavya were the mixed culture of naturally occurring beneficial microbes, mostly lactic acid bacteria (Lactobacillus), yeast (Saccharomyces), actinomyces (Streptomyces), photosynthetic bacteria (Rhodopseudomonas) and certain fungi (Aspergillus) (Xu, 2001; Swaminanthan et al., 2007).

The $\mathrm{pH}$ of panchagavya increased from 6.47 $\left(0^{\text {th }}\right.$ day $)$ to 6.92 ( $28^{\text {th }}$ day). Maximum electrical conductivity was noticed on $28^{\text {th }}$ day $\left(1.78 \mathrm{dSm}^{-1}\right)$. The NPK content of the panchagavya $0.97,0.92$ and $0.65 \%$ was recorded maximum on $21^{\text {st }}$ day after preparation respectively.

\section{Foliar spray on morphological parameters}

Field experiment was conducted to know the changes in morphological, biochemical and yield parameters of Abelmoschus esculentus 
due to panchagavya spray. The morphological parameters of Abelmoschus esculentus at various stages (seedling, flowering and yielding) are shown in table 3 .

The morphological parameters such as plant height, number of leaves, fresh weight and dry weight of Abelmoschus esculentus were increased with the age of the plant. The highest morphological parameters (Plant height 18.23, 68.35 and $74.68 \mathrm{~cm} /$ plant; the fresh weight 25.67, 99.02 and $99.69 \mathrm{mg} /$ plant; and dry weight $9.60,26.12,24.15 \mathrm{mg} /$ plant on seedling, flowering and yielding stage respectively) of Abelmoschus esculentus were recorded in the plants sprayed with 3\% concentration of panchagavya when compared with control as well as other concentrations.

The photosynthetic pigments (chl. A, chl. B, and carotenoid) contents estimated at various growth stages of Abelmoschus esculentus grown under different concentration of panchagavya spray are given in table 4 . The pigment content gradually increased in seedling and flowering, and decreased in yielding stage. The highest pigment contents (chl. A., 0.418, 0.434, and $0.281 \mathrm{mg} /$ plant; chl. B, 0.398, 0.491 and $0.272 \mathrm{mg} /$ plant; carotenoid, $0.361,0.440$ and $0.268 \mathrm{mg} / \mathrm{plant}$ on seedling, flowering and yielding stage respectively) of Abelmoschus esculentus were recorded in the $3 \%$ concentration of panchagavya spray when compared with control and other concentrations.

Plants sprayed with panchagavya invariably produce bigger leaves and develop denser canopy (Somasundaram et al., 2007; Tharmaraj et al., 2011). According to Muthuvel (2002) four sprays of panchagavya at $3 \%$ resulted in higher plant height and number of branches per plant. Present studies revealed that foliar spray of panchagavya at $3 \%$ resulted in significant increase in yield attributes. This is in agreement with the finding of Birendra and Christopher (2007) and Rajesh and Kaliyamoorthy (2013). Similar finding were observed in black gram (Swaminathan et al., 2007) and Coleus forskohili (Kanimozhi, 2004).

Table.1 Ingredients involved in Panchagavya preparation

\begin{tabular}{|c|c|c|}
\hline Sl. No. & Ingredients & Quantity \\
\hline 1 & Fresh cow dung & $5 \mathrm{~kg}$ \\
\hline 2 & Cow's urine & 3 litre \\
\hline 3 & Cow's milk & 2 litre \\
\hline 4 & Cow's curd & 2 litrs \\
\hline 5 & Cow's ghee & $1 / 2 \mathrm{~kg}$ \\
\hline 6 & Jaggery & $1 / 2 \mathrm{~kg}$ in 3 litre of water \\
\hline 7 & Tender Coconut water & 3 litre \\
\hline 8 & Banana (ripe) & 12 nos \\
\hline 9 & Toddy or grape juice & 2 litre \\
\hline
\end{tabular}


Table.2 Changes in Physico-chemical and biological properties of Panchagavya with time

\begin{tabular}{|c|c|c|c|c|c|c|c|c|c|c|}
\hline \multirow[b]{2}{*}{ Sl. No. } & \multicolumn{5}{|c|}{ Available nutrient status } & \multicolumn{2}{|c|}{ Physical properties } & \multicolumn{3}{|c|}{ Microbial load $\left(\right.$ Population $\left.=X \mathrm{cfu} \mathrm{ml}^{-1}\right)$} \\
\hline & $\mathbf{N}$ & $\mathbf{p}$ & $\mathbf{K}$ & $\mathbf{C a}$ & Mg & $\mathbf{E C}\left(\mathrm{dSm}^{-1}\right)$ & $\mathbf{p H}$ & $\begin{array}{c}\text { Bacteria } \\
\left(\mathbf{1 0}^{6}\right)\end{array}$ & Fungi $\left(10^{4}\right)$ & Actinomycetes $\left(10^{3}\right)$ \\
\hline $0^{\text {th }}$ day & 0.18 & 0.02 & 0.24 & 0.54 & 0.81 & 0.62 & 6.47 & 10 & 4 & 8 \\
\hline $14^{\text {th }}$ day & 0.62 & 0.12 & 0.53 & 1.15 & 1.13 & 0.98 & 6.72 & 38 & 14 & 18 \\
\hline $21^{\text {st }}$ day & 0.97 & 0.28 & 0.65 & 1.31 & 1.63 & 1.20 & 6.83 & 110 & 25 & 21 \\
\hline
\end{tabular}

*Values represent mean of three replications

Table.3 The morphological parameters of Abelmoschus esculentus grown under different concentrations of Panchagavya spray

\begin{tabular}{|c|c|c|c|c|c|c|c|c|c|c|c|c|}
\hline \multirow[b]{2}{*}{$\begin{array}{c}\text { Concentrations } \\
\text { of } \\
\text { Panchagavya }\end{array}$} & \multicolumn{4}{|c|}{ Seedling Stage } & \multicolumn{4}{|c|}{ Flowering Stage } & \multicolumn{4}{|c|}{ Yielding Stage } \\
\hline & $\begin{array}{c}\text { Plant } \\
\text { Height } \\
(\mathrm{cm} / \text { plant })\end{array}$ & $\begin{array}{c}\text { Fresh } \\
\text { Weight } \\
\text { (mg/plant) }\end{array}$ & $\begin{array}{c}\text { Dry } \\
\text { weight } \\
\text { (mg/plant) }\end{array}$ & $\begin{array}{l}\text { No. of } \\
\text { leaves }\end{array}$ & $\begin{array}{c}\text { Plant } \\
\text { Height } \\
\text { (cm/plant) }\end{array}$ & $\begin{array}{c}\text { Fresh } \\
\text { Weight } \\
\text { (mg/plant) }\end{array}$ & $\begin{array}{c}\text { Dry weight } \\
\text { (mg/plant) }\end{array}$ & $\begin{array}{l}\text { No. of } \\
\text { leaves }\end{array}$ & $\begin{array}{c}\text { Plant } \\
\text { Height } \\
\text { (cm/plant) }\end{array}$ & $\begin{array}{c}\text { Fresh } \\
\text { Weight } \\
\text { (mg/plant) }\end{array}$ & $\begin{array}{l}\text { Dry weight } \\
\text { (mg/plant) }\end{array}$ & $\begin{array}{l}\text { No. of } \\
\text { leaves }\end{array}$ \\
\hline Control & 16.86 & 24.70 & 7.22 & 3 & 64.24 & 88.29 & 19.52 & 21 & 64.44 & 97.00 & 19.88 & 25 \\
\hline \multirow{2}{*}{$1 \%$} & 14.22 & 18.89 & 8.62 & 4 & 66.70 & 82.24 & 22.37 & 18 & 69.20 & 89.30 & 19.32 & 24 \\
\hline & $(-15.65)$ & $(-23.52)$ & (19.39) & $(33.33)$ & $(3.82)$ & $(-6.85)$ & $(14.60)$ & $(-14.28)$ & $(7.38)$ & $(-7.93)$ & $(2.81)$ & $(-4.16)$ \\
\hline \multirow{2}{*}{$3 \%$} & 18.23 & 25.67 & 9.60 & 5 & 68.35 & 99.02 & 26.12 & 24 & 74.68 & 99.69 & 24.15 & 28 \\
\hline & $(8.12)$ & $(3.92)$ & $(32.96)$ & $(66.66)$ & $(6.39)$ & $(12.15)$ & $(33.81)$ & $(14.28)$ & (15.89) & $(3.05)$ & $(21.47)$ & $(12.00)$ \\
\hline \multirow{2}{*}{$5 \%$} & 14.96 & 19.46 & 8.32 & 4 & 65.45 & 83.54 & 24.11 & 22 & 71.23 & 98.30 & 22.39 & 22 \\
\hline & $(-11.26)$ & $(-21.21)$ & (15.23) & (33.33) & (1.88) & $(-5.37)$ & $(23.51)$ & $(4.76)$ & $(10.53)$ & (1.34) & (12.62) & $(-12.00)$ \\
\hline \multirow{2}{*}{$7 \%$} & 15.28 & 22.55 & 7.47 & 4 & 67.23 & 85.77 & 23.08 & 22 & 70.00 & 90.40 & 23.01 & 24 \\
\hline & $(-9.37)$ & $(-8.70)$ & $(3.46)$ & (33.33) & $(4.65)$ & $(-2.85)$ & (18.23) & $(4.76)$ & $(8.62)$ & $(-6.80)$ & (15.74) & $(-4.00)$ \\
\hline
\end{tabular}

Note: $( \pm)$ percentage over control is expressed in parenthesis 
Table.4 Photosynthetic pigment contents of Abelmoschus esculentus grown under different concentrations of Panchagavya spray

\begin{tabular}{|c|c|c|c|c|c|c|c|c|c|}
\hline \multirow[b]{2}{*}{$\begin{array}{c}\text { Concentrations } \\
\text { of } \\
\text { Panchagavya }\end{array}$} & \multicolumn{3}{|c|}{ Seedling Stage } & \multicolumn{3}{|c|}{ Flowering Stage } & \multicolumn{3}{|c|}{ Yielding Stage } \\
\hline & $\begin{array}{l}\text { Chlorophyll } \\
\text { a (mg/plant) }\end{array}$ & $\begin{array}{l}\text { Chlorophyll } \\
\text { b (mg/plant) }\end{array}$ & $\begin{array}{c}\text { Carotenoi } \\
\text { d } \\
\text { (mg/plant) }\end{array}$ & $\begin{array}{c}\text { Chlorophyll a } \\
\text { (mg/plant) }\end{array}$ & $\begin{array}{c}\text { Chlorophyll b } \\
\text { (mg/plant) }\end{array}$ & $\begin{array}{c}\text { Carotenoi } \\
\text { d } \\
\text { (mg/plant) }\end{array}$ & $\begin{array}{l}\text { Chlorophyll } \\
\text { a (mg/plant) }\end{array}$ & $\begin{array}{l}\text { Chlorophyll } \\
\text { b (mg/plant) }\end{array}$ & $\begin{array}{c}\text { Carotenoid } \\
\text { (mg/plant) }\end{array}$ \\
\hline Control & 0.272 & 0.161 & 0.264 & 0.293 & 0.277 & 0.198 & 0.156 & 0.177 & 0.162 \\
\hline \multirow{2}{*}{$1 \%$} & 0.336 & 0.221 & 0.272 & 0.321 & 0.342 & 0.188 & 0.211 & 0.188 & 0.157 \\
\hline & $(23.52)$ & $(37.26)$ & $(3.03)$ & $(9.55)$ & $(23.46)$ & $(-5.05)$ & $(35.25)$ & $(6.21)$ & $(-3.08)$ \\
\hline \multirow{2}{*}{$3 \%$} & 0.418 & 0.298 & 0.361 & 0.434 & 0.491 & 0.340 & 0.281 & 0.272 & 0.268 \\
\hline & $(53.67)$ & $(85.09)$ & (36.74) & $(48.12)$ & $(77.25)$ & (71.71) & $(80.12)$ & (53.67) & $(65.43)$ \\
\hline \multirow{2}{*}{$5 \%$} & 0.322 & 0.210 & 0.275 & 0.345 & 0.322 & 0.289 & 0.167 & 0.271 & 0.261 \\
\hline & (18.38) & $(30.43)$ & $(4.16)$ & (17.74) & (16.24) & $(45.95)$ & $(7.05)$ & $(53.10)$ & $(61.11)$ \\
\hline \multirow{2}{*}{$7 \%$} & 0.302 & 0.193 & 0.278 & 0.317 & 0.312 & 0.184 & 0.201 & 0.182 & 0.172 \\
\hline & $(11.02)$ & (19.87) & $(5.30)$ & $(8.19)$ & $(12.63)$ & $(-7.07)$ & $(28.84)$ & $(2.82)$ & (6.17) \\
\hline
\end{tabular}

Note: $( \pm)$ percentage over control is expressed in parenthesis

Table.5 Yield parameters of Abelmoschus esculentus grown under different concentrations of Panchagavya spray

\begin{tabular}{ccc}
\hline Concentration & No. of fruits/plant & Fruit Weight (mg/fruit) \\
\hline Control & 11 & 26.82 \\
$\mathbf{1 \%}$ & 14 & 21.66 \\
& $(27.27)$ & $(19.23)$ \\
$\mathbf{3 \%}$ & 19 & 30.67 \\
& $(72.72)$ & $(14.35)$ \\
$\mathbf{5 \%}$ & 17 & 23.44 \\
& $(54.54)$ & $(12.60)$ \\
$\mathbf{7 \%}$ & 18 & 21.28 \\
& $(63.63)$ & $(20.65)$ \\
\hline \multicolumn{2}{l}{ Note: $( \pm)$ percentage over control is expressed in parenthesis }
\end{tabular}


The photosynthetic pigments content such as chl. A, chl. B and carotenoid of Abelmoschus esculentus were increased in $3 \%$ panchagavya spray and decreased in control and other concentration. Similar findings were observed in Arachis hypogaea (Subramaniyan, 2005) and Vigna radiate, Vigna mungo and Oryza sativa (Tharmaraj, 2011).

\section{Foliar spray on yield}

The yield parameters such as number of fruit and fruit weight of Abelmoschus esculentus sprayed with different concentration of Panchagavya is presented in table 5. The highest yield parameters such as number of fruit (19), and fruit weight (30.67 mg/fruit) of Abelmoschhus esculentus were recorded in the plants sprayed with 3\% concentration of panchagavya when compared with control as well as other concentrations.

Using panchagavya helps to increase the and more yield and quality of the products (Subramaniyan, 2005) as compared to chemical fertilizers, this is less expensive and more ecofriendly with no side effects. The yield parameters (number of fruit, and fruit weight of Abelmoschus esculentus were increased in $3 \%$ panchagavya spray when compared with control and other concentration.

Similar findings were observed in Vigna mungo and Oryza sativa (Rajasekaran and Balakrishanan, 2002), black gram and green gram (Brito and Girija, 2006) and groundnut (Ravikumar et al., 2012). Panchagavya enhances the growth and vigour of crops, inducing resistance to pests and diseases and improving the keeping quality of vegetables and fruits (Natarajan, 2002). Panchagavya spray was also reported as effective on all the crops than the recommended nutrients and growth (RFS) in terms of higher growth and productivity.
The present research work was carried out to study the effect of panchagavya spray on gowth, yield and biochemical changes in Abelmoschus esculentus. All parameters were increased in 3\% concentration. Since, there was increase in growth and yield at low concentration of panchagavya, it is recommended that the panchagavya can be used for spray after diluted properly. Cow's urine provides nitrogen which is essential for crop growth.

Milk provides protein, fat, carbohydrates, amino acid and calcium. Curd provides lactobacillus which act as catalyst in the digestion of organic waste. Ghee provides vitamins $\mathrm{A}$ and $\mathrm{B}$, calcium and fat. These contents stimulate the growth and yield of all vegetable crops.

\section{References}

Amalraj, E.L.D., K.G. Praveen, S.K. Mir Hassan Ahmed, R. Abdul and N. Kishore. 2013. Microbiological analysis of panchagavya, vermicompost, and FYM and their effect on plant growth promotion of pigeon pea (Cajanus cajan L.) in Indian. Organic Agriculture, 3: 23-29.

Arnon, D.I., 1949. Copper enzyme in isolated chloroplast - Polyphenol oxidase in Beta vulgaris. Plant Physiology, 24: 1-15.

Birendra, K.Y., and L.A. Christopher. 2007. Use of panchagavya as a growth stimulant and biopesticide in agriculture. In: Agriculture and Environment. Ed. Arvind Kumar, APH Publishing Corporation, New Delhi, pp. 6570.

Brito, D.J., and S. Girija. 2006. Investigation on the effect of organic and inorganic farming methods on black gram and green gram. Indian J. Agric. Res., 40: 204-207.

Jackson, M.L., 1967. Soil chemical analysis. Prentice Hall India Pvt. Ltd. New Delhi, pp-498.

Jackson, M.L., 1973. Soil chemical analysis: Advanced Course, second edition, Madison, Wisconsin, USA, p. 511. 
Kanimozhi, S., 2004. Standardization of organic production package of Coleus forskohlii. M.Sc. Thesis, Horticultural College and Research Institute, Tamil Nadu Agriculture University, Coimbatore, T.N. (India).

Kannaiyan, K., 2000. Bioferitilizers: Key Factors in Organic Farming. The Hind Survey of Indian International Journal of Modern Plant \& Animal Sciences, 1(2): 82-95.

Krik, J.T.O., and R.L. Allen. 1965. Dependence of chloroplast pigments synthesis on protein synthetic effects of acitilione. Biochem. Biophys. Res. Comm., 27: 523-530.

Muthuvel, 2002. Effect of organics on growth and yield of bhendi var. Varsh Uphar. Proc. Nation. Conf. on glory of gomatha: panchagavya as potentiator of plant cells: effects on crop plants and the physiology that validates the effects. Dec, 1-3. 2007, S.V. Veterinary Univ., Tirupati, A.P., pp. 143-148.

Naik, N., and M.N. Sreenivasa. 2009. Influence of bacterial isolated from Panchagavya on seed germination and seed vigour in wheat. Karnataka Journal of Agricultural Sciences, 22(1): 231-232.

Natarajan, K., 2002. Panchagavya - A Manual. Other Indian Press, Mapusa, Goa, India, pp. 333.

Prabhu, M.J., 2004. Dasagavya-organic growth promoter for plants. www.Hindu.com/seta /2004/02/12.

Rajasekaran, M., and S. Balakrishna. 2002. A study on the effect of panchagavya and growth of Oryza sativa L., Zea mays (L) and Vigna mungo. M. Phil. Thesis.

Rajesh, M., and J. Kaliyamoorthy. 2013. Changes in morphological, biochemical and yield parameters of Abelmoschus esculentus (L.) oench due to panchagavya spray. International Journal of Modern Plant \&
Animal Sciences, 1(2):82-95.

Ravikumar, H.S., N. Janakiraman, T. Sheshadri, J. Venkate and G. Vijaymahantesh. 2012. Integrated organic nutrient supply systems on growth and yield of groundnut. Environ. Ecol., 30: 118-121.

Selvaraj, N., 2003. Report on the Work Done on Organic Farming at Horticulture Research Station. Tamil Nadu Agricultural University, Ooty, India, pp. 2-5.

Somasundaram, E., N. Sankaran, S. Meena, T.M. Thiyagarajan, K. Chandaragiri and S. Panneerselvam. 2007. Response of greengram to varied levels of Panchagavya (organic nutrition) foliar spray. Madras Agriculture Journal, 90: 169-172.

Subramaniyan, A., 2005. Effect of Panchagavya on Escherchia coli in procured milk. Indian Veterinary journal, 82: 799-800.

Swaminathan, C., V. Swaminathan and V. Vijayalakshmi. 2007. Panchagavya Boon to Organic Farming. International Book Distributing Corporation, India.

Tharmaraj, K., P. Ganesh, R. Sureshkumar, A. Anandan and K. Kolanjinathan. 2011. A Critical Review on Panchagavya - A boon plant growth. Int. J. Pharm. Biol. Arch., 2(6): 1611-1614.

Thomas, G.V., and S.R. Prabhu. 2001. Bioinoculants and organic amendments for ensuring crop health in sustainable agriculture, in biological control of pests, Deshmukh, A.M. (ed.), published by desmukh Karad, S.A., India, pp. 122-162.

Xu, H.L., 2001. Effects of a microbial inoculants and organic fertilizers on the growth, photosynthesis and yield attributes and economics of rice (Oryza sativa). Crop Research, 31: 1-5.

\section{How to cite this article:}

Suchitra Rakesh, S. Poonguzhali, B. Saranya, S. Suguna and Jothibasu, K. 2017. Effect of Panchagavya on Growth and Yield of Abelmoschus esculentus cv. Arka Anamika. Int.J.Curr.Microbiol.App.Sci. 6(9): 3090-3097. doi: https://doi.org/10.20546/ijcmas.2017.609.380 